No 4078

Studia nad Autorytaryzmem i Totalitaryzmem 43, nr 4 Wrocław 2021

https://doi.org/10.19195/2300-7249.43.4.9

\author{
DARIA KOSTECKA-JURCZYK \\ ORCID: 0000-0002-8404-7791 \\ Uniwersytet Wrocławski \\ daria.kostecka-jurczyk@uwr.edu.pl
}

\title{
Zmiany organizacyjno-prawne przedsiębiorstwa państwowego w okresie Polskiej Rzeczypospolitej Ludowej
}

Słowa kluczowe: przedsiębiorstwo państwowe, gospodarka nakazowa, działalność gospodarcza państwa autorytarnego, gospodarka centralnie planowana, nadzór założycielski, własność państwowa.

\section{ORGANIZATIONAL AND LEGAL CHANGES OF A STATE-OWNED ENTERPRISE IN THE PERIOD OF THE PEOPLE'S REPUBLIC OF POLAND}

\begin{abstract}
In Poland, during the People's Republic of Poland, the policy of central management of the economy was based on the principles of unity of state power and unity of state property. They constituted the foundation of the state sector and the state economic activity. State-owned enterprises, strongly subordinated to public administration bodies, were the leading form of economic activity. The authoritarian state controlled not only the process of enterprise creation, liquidation and supervision, but also the enterprises' operational activities. Strong state supervision and lack of responsibility for financial results were the main reasons for their low profitability, which in turn brought about attempts to reform the legal structure of the state-owned enterprises. The aim of the article is to show the legal and organizational changes in state-owned enterprises that are to produce an increase in economic efficiency. Based on the historical-legal method and the grammatical interpretation of the law, it was shown that the reforms undertaken in the field of the organization of state-owned enterprises were not effective.
\end{abstract}

Keywords: state-owned enterprise, command economy, centrally planned economy, economic activity of the authoritarian state, founding supervision, state property. 


\section{Wprowadzenie}

W wielu krajach przedsiębiorstwa państwowe powstawały już w XIX wieku w celu realizacji zadań społecznych. Skala państwowej działalności gospodarczej wzrosła po I wojnie światowej, głównie ze względu na potrzeby militarne. Natomiast po II wojnie światowej sektor państwowy zdominował gospodarki krajów socjalistycznych i obejmował praktycznie wszystkie ich obszary. Trzeba jednak zaznaczyć, że niemałą rolę odegrał on także w krajach kapitalistycznych, między innymi w Niemczech, Hiszpanii, Francji, Wielkiej Brytanii, Włoszech i Japonii, czemu sprzyjały procesy nacjonalizacyjne ${ }^{1}$.

W Polsce po wojnie na mocy ustawy nacjonalizacyjnej przeszły na własność państwa przedsiębiorstwa przemysłowe, górnicze, komunikacyjne, ubezpieczeniowe, handlowe należące do Rzeszy Niemieckiej i byłego Wolnego Miasta Gdańska oraz ich obywateli ${ }^{2}$. Regulacji tej nie podlegały przedsiębiorstwa stanowiące własność samorządowych związków międzykomunalnych oraz spółdzielni i ich związków ${ }^{3}$. Podstawową formą organizacyjno-prawną gospodarczej działalności państwa było wówczas przedsiębiorstwo państwowe.

\section{Konstrukcja przedsiębiorstwa państwowego jako formy działalności gospodarczej państwa}

Przedsiębiorstwo państwowe w znaczeniu ekonomicznym stanowiło wyodrębnioną jednostkę prowadzącą działalność produkcyjną, handlową lub usługo$\mathrm{wą}^{4}$. W ujęciu prawnym pojęcie to łączono z kompleksem praw służących gospodarczemu celowi osoby, która zarządzała taką jednostką ${ }^{5}$. Odnosiło się ono się nie tylko do działalności nastawionej na osiąganie zysku, ale też takiej, której celem było zaspokojenie potrzeb różnych podmiotów społecznych, w tym przedsiębiorców i osób fizycznych, z wykorzystaniem mienia państwowego ${ }^{6}$.

${ }^{1}$ R. Green, J. Haskel, Seeking a Premier League Economy. The role of Privatisation, London 2000 , s. 5.

2 Ustawa z dnia 3 stycznia 1946 roku o przejęciu na własność państwa podstawowych gałęzi gospodarki narodowej (Dz.U. z 1946 r. Nr 3, poz. 17); Dekret z dnia 8 marca 1946 roku o majątkach opuszczonych i poniemieckich (Dz.U. z 1946 r. Nr 13, poz. 87).

3 J. Szachułowicz, Własność publiczna. Powstanie, przeksztatcanie, funkcje, zarzadzanie, Warszawa 2000, s. 37 n.

${ }^{4}$ Elementarne zagadnienia ekonomii, red. R. Milewski, Warszawa 2002, s. 160; S. Sudo1, Przedsiębiorstwo. Podstawy nauki o przedsiębiorstwie. Teorie i praktyka zarządzania, Toruń 1999, s. 34-39.

5 W.L. Jaworski, Nauka prawa administracyjnego. Zagadnienia ogólne, Warszawa 1924, s. 151.

6 D. Kostecka, Komercjalizacja przedsiębiorstwa państwowego, Wrocław 2006, s. 53 n. 
Obowiązująca w okresie Polskiej Rzeczpospolitej Ludowej zasada jedności własności państwowej oznaczała, że własność ogólnonarodowa ,przysługiwała niepodzielnie państwu". Zatem było ono jedynym właścicielem składników mienia państwowego, którym zarządzało za pośrednictwem państwowych osób prawnych oraz niemających osobowości prawnej państwowych jednostek organizacyjnych. Przedsiębiorstwa państwowe, podobnie jak inne państwowe osoby prawne, otrzymywały mienie należące do Skarbu Państwa tylko w tak zwany zarząd. Organ założycielski utrzymywał jednak kontrolę nad przekazanym przedsiębiorstwu mieniem i wywierał istotny wpływ na sposób zarządzania organizacją, która z tego mienia korzystała. Przejawem tego była konieczność uzyskania zgody na dokonanie czynności rozporządzających.

Organizację przedsiębiorstwa państwowego wzorowano początkowo na rozporządzeniu prezydenta Rzeczypospolitej z 1927 roku, które obowiązywało do czasu wydania dekretu z 1947 roku, odwołującego się do zasad gospodarki planowej ${ }^{7}$. Przedsiębiorstwa państwowe włączono wówczas w system centralnego planowania, a ich celem stało się wykonywanie zadań wynikających z narodowego planu gospodarczego. W efekcie ich działalność sprowadzała się do realizacji planu bez względu na wyniki finansowe ${ }^{8}$.

Przedsiębiorstwa państwowe były tworzone na mocy zarządzenia właściwego ministra w porozumieniu z ministrem skarbu i prezesem Centralnego Urzędu Planowania (CUP). Podstawą działalności przedsiębiorstwa państwowego były dekret oraz zawierający szczegółowe postanowienia statut ${ }^{9}$. Jego organem zarządzającym była dyrekcja, powoływana i odwoływana przez właściwego ministra lub podległe mu organy, bądź też zjednoczenia albo zarządy centralne. Liczbę członków dyrekcji określał statut. Nadzór nad przedsiębiorstwem sprawowali właściwy minister, zjednoczenia i zarządy centralne.

W 1950 roku wspomniany dekret został uchylony i zastąpiony dekretem o przedsiębiorstwach państwowych ${ }^{10}$, który obowiązywał do czasu wejścia w życie ustawy o przedsiębiorstwach państwowych z dnia 25 września 1981 roku ${ }^{11}$. Akt ten nie miał zastosowania do państwowych instytucji bankowych, Polskich Kolei Państwowych, Polskiej Poczty, Telegrafu i Telefonu oraz państwowych gospodarstw

${ }^{7}$ Dekret o tworzeniu przedsiębiorstw państwowych z dnia 3 stycznia 1947 roku, Dz.U. z 1947 r. $\mathrm{Nr} 8$, poz. 42.

${ }^{8}$ S. Buczkowski, Z.K. Nowakowski, Prawo obrotu uspołecznionego, Warszawa 1974, s. 54 n.; M. Stelmachowski, Zarys prawa cywilnego, Kraków 1995, s. 93 n.

9 S. Buczkowski, Przedsiębiorstwo państwowe. Charakterystyka prawna, Warszawa 1948, s. 50 .

10 Zob. A. Chełmoński, Założenia wstępne struktury prawnej przedsiębiorstw państwowych, „Państwo i Prawo” 1950, nr 7, s. 8 n; Dekret z 26 października 1950 roku o przedsiębiorstwach państwowych, Dz.U. z 1960 r. Nr 18, poz. 111 (dalej: dekret z 1950 roku).

11 Ustawa z dnia 25 września 1981 roku o przedsiębiorstwach państwowych, Dz.U. z 2002 r. Nr 112, poz. 981 ze zm. (dalej: ustawa o p.p.). 
leśnych. Miały one szczególny reżim prawny, polegający na zakazie zbywania środków trwałych na rzecz osób niebędących jednostkami gospodarki uspołecznionej.

W 1956 roku w przedsiębiorstwach państwowych na mocy ustawy utworzono rady robotnicze ${ }^{12}$, które uczestniczyły w procesie zarządzania firmą. Ich ustanowienie było przejawem rozluźnienia scentralizowanego zarządu własnością ogólnonarodową i budziło nadzieję na wdrożenie w przyszłości korporacyjnych metod zarządzania. Prawno-organizacyjna konstrukcja przedsiębiorstwa państwowego była bowiem nieadekwatna do zachodzących już wówczas zmian w ustroju społeczno-gospodarczym, zwłaszcza koncentracji potencjału wytwórczego, zainteresowania pracowników efektywnym gospodarowaniem i ich udziałem w zarządzaniu przedsiębiorstwem.

\section{W kierunku ekonomicznego racjonalizmu}

Głęboki kryzys społeczno-gospodarczy w latach siedemdziesiątych, przejawiający się między innymi drastycznym wzrostem długu zagranicznego i spadkiem poziomu życia ludności, wymusił zmianę podejścia do zarządzania przedsiębiorstwami państwowymi ${ }^{13}$. Jednym z kluczowych rozwiązań była decentralizacja kompetencji decyzyjnych $\mathrm{w}$ przedsiębiorstwach państwowych, czego skutkiem było zwiększenie zaangażowania ich organów w procesy zarządzania. Istotnym czynnikiem motywującym do podniesienia wydajności było uzależnienie funduszu płac przedsiębiorstw od wzrostu produkcji netto, względnie od wzrostu ilości produkcji w wyrażeniu naturalnym (głównie w gałęziach wydobywczych), a także przyznanie państwowym firmom szerokich uprawnień w zakresie dysponowania funduszem płac.

$\mathrm{Na}$ początku lat osiemdziesiątych pojawiła się także tendencja do ograniczania nakazowej metody zarządzania, czego przejawem była uchwała Rady Ministrów z 17 listopada 1980 roku w sprawie zmian w systemie kierowania przedsiębiorstwami państwowymi ${ }^{14}$. Proces tych przeobrażeń nazwano małą reformą gospodarczą. Polegały one w głównej mierze na ograniczeniu narzucanych planów produkcji, ale nie zmieniły powszechnie krytykowanego systemu nakazowo-rozdzielczego ${ }^{15}$. $\mathrm{Z}$ tego względu mała reforma nie odegrała istotnej roli

12 Ustawa z dnia 19 listopada 1956 roku o radach robotniczych, Dz.U. z 1956 r. Nr 52, poz. 238.

13 Rozporządzenie Rady Ministrów z 6 lutego 1976 roku w sprawie warunków, trybu i organów właściwych do wydawania zagranicznym osobom prawnym i fizycznym uprawnień do tworzenia przedstawicielstw na terytorium Polskiej Rzeczypospolitej Ludowej dla wykonywania działalności gospodarczej, Dz.U. z 1976 r. Nr 11, poz. 63, oraz uchwała Rady Ministrów nr 24 z 7 lutego 1979 roku w sprawie tworzenia i działalności w kraju przedsiębiorstw z udziałem kapitału zagranicznego, M.P. z 1979 r. Nr 4, poz. 36.

${ }^{14}$ Uchwała Rady Ministrów z dnia 17 listopada 1980 roku w sprawie zmian w systemie kierowania przedsiębiorstwami państwowymi, M.P. z 1980 r. Nr 80, poz. 165

15 Zob. J. Wiszniewski, Prawo gospodarcze, Warszawa 1982, s. 67 n. 
w procesie ekonomizacji i uniezależniania przedsiębiorstw od organów administracji państwowej. Ich działalność wciąż była podporządkowana planom gospodarczym, których realizacja była obowiązkiem. Istotne zmiany zaczęto wdrażać dopiero po 1981 roku.

\section{Reformy wdrażane po 1981 roku}

W 1981 roku uchwalono ustawy o przedsiębiorstwach państwowych ${ }^{16}$ i o samorządzie załogi przedsiębiorstw państwowych ${ }^{17}$, które zastąpiły dekret z 1950 roku $^{18}$ oraz ustawę o samorządzie robotniczym z 20 listopada $1958 \mathrm{roku}^{19}$. Wyodrębniono wówczas przedsiębiorstwa działające na zasadach ogólnych i przedsiębiorstwa użyteczności publicznej. Odrębną kategorię stanowiły przedsiębiorstwa mieszane, to znaczy utworzone przez przedsiębiorstwo państwowe wspólnie z innymi osobami prawnymi i fizycznymi. Jednocześnie ustawodawca sformułował trzy zasady, które miały być fundamentem zarządzania przedsiębiorstwem państwowym — zasady samodzielności, samorządności i samofinansowania. Samodzielność miała przejawiać się w oderwaniu zasad funkcjonowania przedsiębiorstw od reżimu scentralizowanego państwa i była utożsamiana z prawem do samodzielnego działania i podejmowania pewnych decyzji przez organy zarządzające. Samorządność z kolei wiązała się z dopuszczeniem udziału załogi $\mathrm{w}$ procesie podejmowania decyzji operacyjnych i strategicznych związanych z działalnością przedsiębiorstwa. Samofinansowanie natomiast miało wymusić jego funkcjonowanie na podstawie rachunku ekonomicznego i ponoszenie przez dyrektora pełnej odpowiedzialności za wyniki ekonomiczne ${ }^{20}$. Jednak praktyczne zastosowanie tych reguł okazało się niezwykle trudne. Główną przeszkodą była wciąż silna centralizacja systemu zarządzania gospodarką narodową i narzucane przedsiębiorstwom plany produkcji. Wiele z nich nie przestrzegało zasady samofinansowania, korzystając $\mathrm{z}$ różnych form pomocy finansowej ze strony państwa (dotacje, kredyty subsydiowane). Realna możliwość podejmowania samodzielnych decyzji przez organy przedsiębiorstwa wciąż była mocno ograniczona. Brakowało im bowiem autonomii w zakresie bieżącego zarządzania, a organy założycielskie nie dysponowały mechanizmami egzekwowania odpowiedzialności za gospodarkę finansową przedsiębiorstwa. W konsekwencji niemożliwe stało się wymuszenie efektywności ekonomicznej. Sankcje za brak rentowności nie były

16 Ustawa o p.p.

17 Ustawa z dnia 25 września 1981 roku o samorządzie załogi przedsiębiorstw państwowych, Dz.U. z 1981 r. Nr 24, poz. 123 ze zm.

18 Dekret z 1950 roku.

19 Ustawa o samorządzie robotniczym z dnia 20 listopada 1958 roku, Dz.U. z 1958 r. Nr 77, poz. 397.

20 Polska reforma gospodarcza, oprac. W. Baka, Warszawa 1983, s. 74. 
praktycznie stosowane, nie premiowano też wysiłków stwarzających szanse rozwoju $^{21}$. Nie było zatem narzędzi motywujących do racjonalizacji zarządzania.

Przejawem pozytywnych zmian w zakresie zarządzania przedsiębiorstwem było uniezależnienie dyrektora od organów administracji państwowej i partyjnej. W ustawie o p.p. wprowadzono bowiem obowiązek powoływania na to stanowisko przez radę pracowniczą (w drodze konkursu lub w ustawowo określonych przypadkach przez organ założycielski). Celem takiego rozwiązania miało być stworzenie szansy na wyłonienie sprawnych menedżerów w oderwaniu od partyjnych rekomendacji. Rada pracownicza była bowiem organem wybieranym przez wszystkich pracowników i reprezentującym przedsiębiorstwo. Taki sposób wyboru jej członków miał na celu ograniczenie wpływu administracji państwowej i partyjnej na działalność przedsiębiorstwa. Jedynie w firmach o szczególnym znaczeniu dla gospodarki państwa oraz przedsiębiorstwach użyteczności publicznej obowiązywała zasada powoływania dyrektora przez organ założycielski. Należy jednak zaznaczyć, że funkcjonujące obok dyrekcji organy samorządu załogi, to jest ogólne zebranie pracowników oraz rada pracownicza, de facto powodowały osłabienie pozycji władz zakładu 22 .

Aby zapobiec negatywnym skutkom tego rozwiązania, w 1982 roku ${ }^{23}$ organy założycielskie i dyrektorzy przedsiębiorstw zostali wyposażeni w szerokie kompetencje w zakresie kontrolowania działalności samorządu załogi. Dotyczyły one możliwości zawieszania i wznawiania działalności samorządu; osłabiono też moc prawną sprzeciwu organów samorządu i dyrektora wobec decyzji jednostek nadrzędnych. Jednak już rok później organy założycielskie otrzymały dodatkowe uprawnienia do decydowania o sytuacji dyrektorów przedsiębiorstw państwowych w zakresie stosunku pracy ${ }^{24}$. Ponadto ponownie zostali oni uzależnieni od organu założycielskiego w kwestii wynagrodzenia za pracę, nawiązania stosunku pracy, oceny i kontroli. W konsekwencji kolejny raz ograniczono możliwość sprawnego zarządzania przedsiębiorstwem przez dyrektora. Nie mógł on samodzielnie podejmować decyzji w sprawach zatrudnienia, kształtowania poziomu cen czy profilu produkcji.

Pozornie przedsiębiorstwa państwowe miały autonomię w stosunkach z organem założycielskim. Mogły bowiem wyrazić sprzeciw wobec jego decyzji

${ }^{21}$ L. Stępniak, Próba oceny funkcjonowania ustaw o przedsiębiorstwach państwowych i samorządzie załogi, „Przegląd Ustawodawstwa Gospodarczego” 1985, nr 7, s. 196.

22 A. Walaszek-Pyzioł, Organy przedsiębiorstwa państwowego a zasada jednoosobowego kierownictwa, „Krakowskie Studia Prawnicze” 18, 1985, s. 55 n.

${ }^{23}$ Ustawa z dnia 18 grudnia 1982 roku o szczególnej regulacji prawnej w okresie zawieszenia stanu wojennego, Dz.U. z 1982 r. Nr 41, poz. 273.

24 Ustawa z dnia 21 lipca 1983 roku o szczególnej regulacji prawnej w okresie przezwyciężania kryzysu społeczno-ekonomicznego oraz o zmianie niektórych ustaw, Dz.U. z 1983 r. Nr 39, poz. 175 . 
i w efekcie doprowadzić do wstrzymania wykonania uchwały lub decyzji ${ }^{25}$. Organy przedsiębiorstwa miały też możliwość odwołania się od decyzji organów założycielskich, ze skargą sądową włącznie. Podmiotami uprawnionymi do korzystania $\mathrm{z}$ tych środków byli dyrektor i rada pracownicza. Jednak mimo tego organ założycielski nadal miał wyłączne prawo powoływania i odwoływania dyrektora nowo tworzonego przedsiębiorstwa (w przedsiębiorstwach użyteczności publicznej w każdym przypadku), w tym na wniosek rady pracowniczej. Posiadał też władcze kompetencje wobec organów samorządu załogi (rady pracowniczej i ogólnego zebrania delegatów), związane z rozpatrywaniem wnoszonych przez nie sprzeciwów.

W 1988 roku w znacznym stopniu ograniczono prawa reprezentacji pracowniczej w przedsiębiorstwie ${ }^{26}$. Wprowadzono też możliwość odwoływania dyrektorów, dokonywania połączeń, podziałów i likwidacji przedsiębiorstw bez zgody rady pracowniczej. Te rozwiązania miały ograniczyć nieformalny wpływ załogi i związków zawodowych na sprawy zakładu, co później mogło ułatwiać podejmowanie decyzji prywatyzacyjnych.

\section{Podsumowanie}

Formę organizacyjno-prawną prowadzenia przez państwo autorytarne działalności gospodarczej, czyli przedsiębiorstwo państwowe, wielokrotnie modyfikowano w okresie kilkudziesięciu lat. Liczne reformy przedsiębiorstwa państwowego nie były jednak w stanie sprostać coraz poważniejszym wyzwaniom gospodarczym. Usprawnienie zarządzania nimi miało wymusić wdrożenie zasad samodzielności, samorządności i samofinansowania. W praktyce były one jednak realizowane $\mathrm{w}$ ograniczonym stopniu. Wynikało to $\mathrm{z}$ reguly centralizmu planowania i zarządzania gospodarką. Zdolność racjonalnego zarządzania uniemożliwiała bowiem konieczność realizacji planów narzucanych przez organy centralne. W efekcie przedsiębiorstwa państwowe miały problemy z płynnością finansową i były uzależnione od pomocy państwa. Istotną barierą były także wzajemne zależności między dyrektorami przedsiębiorstw państwowych a organami przedstawicielskimi pracowników i organami założycielskimi, które uniemożliwiały podejmowanie racjonalnych decyzji. System funkcjonowania tego typu zakładów był dość sformalizowany, co ograniczało ich elastyczność w procesie gospodarowania i ciągłego dostosowywania się do sytuacji rynkowej. Konstrukcja zarządzania nim

25 Zob. L. Bar, Ochrona praw przedsiębiorstwa państwowego i samorządu jego załogi, „Państwo i Prawo” 1983, nr 10, s. 7; K. Pawłowicz, Sądowa kontrola przedsiębiorstw, „Życie Gospodarcze" 1985, nr 40, s. 7; M. Tyczka, Postępowanie sądowe w sprawach zwiąanych z działalnościa przedsiębiorstw państwowych i ich samorządów, „Ruch Prawniczy, Ekonomiczny i Socjologiczny” 1982, nr 2; B. Banaszak, Otwarta droga do sadu, „Rzeczpospolita” 27.01.2005.

${ }^{26}$ Ustawa z dnia 11 maja 1988 roku o nadzwyczajnych uprawnieniach i upoważnieniach Rady Ministrów, Dz.U. z 1988 r. Nr 13, poz. 98. 
była wadliwa, bazowała bowiem na dychotomii zarządu. Decyzje w sprawach przedsiębiorstwa podejmował dyrektor, ale mogły to czynić również inne organy w jego strukturze, będące jednocześnie organami samorządu załogi. Należy pamiętać także o tym, że dyrektor w pewnym zakresie był uzależniony od samorządu pracowniczego, gdyż posiadał on istotny wpływ na jego powoływanie i odwoływanie. W rzeczywistości przedsiębiorstwa państwowe funkcjonowały w sieci wzajemnych zależności między organem założycielskim a instytucjami planowania.

\section{Bibliografia}

\section{Literatura}

Banaszak B., Otwarta droga do sadu, „Rzeczpospolita” 27.01.2005.

Bar L., Ochrona praw przedsiębiorstwa państwowego i samorządu jego załogi, „Państwo i Prawo” 1983, nr 10.

Buczkowski S., Nowakowski Z.K., Prawo obrotu uspołecznionego, Warszawa 1974.

Buczkowski S., Przedsiębiorstwo państwowe. Charakterystyka prawna, Warszawa 1948.

Chełmoński A., Założenia wstępne struktury prawnej przedsiębiorstw państwowych, „Państwo i Prawo" 1950, nr 7.

Chwiałkowska J., Sektor państwowy w gospodarce rynkowej, [w:] Gospodarka, administracja, samorzad, red. H. Olszewski, B. Popowska, Poznań 1997.

Elementarne zagadnienia ekonomii, red. R. Milewski, Warszawa 2002.

Green R., Haskel J., Seeking a Premier League Economy. The role of Privatisation, London 2000.

Jaworski W.L., Nauka prawa administracyjnego. Zagadnienia ogólne, Warszawa 1924.

Kosikowski C., Prawo zarzadzania gospodarka narodowa, Warszawa 1991.

Kostecka D., Komercjalizacja przedsiębiorstwa państwowego, Wrocław 2006.

Pawłowicz K., Sadowa kontrola przedsiębiorstw, „Życie Gospodarcze” 1985, nr 40.

Polska reforma gospodarcza, oprac. W. Baka, Warszawa 1983.

Przedsiębiorstwo państwowe w nowym systemie planowania i zarządzania gospodarka narodowa, red. J. Grabowski, Katowice 1986.

Stelmachowski M., Zarys prawa cywilnego, Kraków 1995.

Stępniak L., Próba oceny funkcjonowania ustaw o przedsiębiorstwach państwowych i samorządzie załogi, „Przegląd Ustawodawstwa Gospodarczego” 1985, nr 7.

Sudoł S., Przedsiębiorstwo. Podstawy nauki o przedsiębiorstwie. Teorie i praktyka zarzadzania, Toruń 1999.

Szachułowicz J., Własność publiczna. Powstanie, przekształcanie, funkcje, zarządzanie, Warszawa 2000.

Tyczka M., Postępowanie sadowe $w$ sprawach zwiazanych $z$ działalnościa przedsiębiorstw państwowych i ich samorzadów, „Ruch Prawniczy, Ekonomiczny i Socjologiczny” 1982, nr 2.

Walaszek-Pyzioł A., Organy przedsiębiorstwa państwowego a zasada jednoosobowego kierownictwa, „Krakowskie Studia Prawnicze” 18, 1985.

Wiszniewski J., Prawo gospodarcze, Warszawa 1982.

Włodyka S., Prawo gospodarcze. Zarys systemu, t. 1. Czesść ogólna, Warszawa 1981.

Wojtyna A., Nowe kierunki badań nad ekonomiczna rola państwa, „Ekonomista” 2001, nr 1.

Wostal M., Charakter prawny form oddziaływania zjednoczeń na przedsiębiorstwa państwowe, Warszawa-Poznań 1975.

Żabińska J., Miejsce i rola państwa w gospodarce rynkowej, „Gospodarka Narodowa” 1991, nr 9. 